\title{
KESESUAIAN EKOSISTEM TERUMBU KARANG UNTUK KEGIATAN WISATA SELAM DI NUSA LEMBONGAN, BALI
}

\author{
Made Ayu Pratiwi*, Ni Made Ernawati, Ni Putu Putri Wijayanti \\ Program Studi Manajemen Sumberdaya Perairan, Fakultas Kelautan dan Perikanan, Universitas \\ Udayana, Kampus Bukit Jimbaran, Bali-Indonesia \\ *Email: mayupratiwi@unud.ac.id
}

\section{ABSTRACT \\ SUITABILITY OF CORAL REEF ECOSYSTEMS FOR DIVING TOURISM ACTIVITIES IN NUSA LEMBONGAN, BALI}

Nusa Lembongan islands, Bali have a potential of coral reef diversity. Coral reefs have both ecological and high economic potential so that they are widely used. The economic benefits of coral reefs make these ecosystems very vulnerable to pressure from human activities. One of these human activities is the use of coral reefs in diving tourism activities. This research aimed to determine suitability and carrying capacity of coral reef ecosystem on Nusa Lembongan Island so that it can be recommended to manage coral reef ecosystem strategies to support the use of diving tourism. This study was conducted on six dive sites as observation points Observations on coral reef ecosystems were carried out using the intercept transect (LIT) method, and reef fish observation was carried out using the fish visual census method. Water quality sampling will be done in situ. Diving suitability was carried out by estimating the tourist suitability index (IKW) of six parameters, namely the brightness of the waters, coral community cover, coral life form, reef fish species, coral reef depth and current. The tourism suitability index value for the diving tourism category obtained was $74.07 \%$ (Jack Mangrove); 57.41\% (Crystal Bay); and 61.11\% (Manta Bay). The value for each observation point is included in the appropriate category of $50 \%-75 \%$. It can be interpreted, that all observation points which are dive sites in Nusa Lembongan have supported diving tourism activities.

Keywords: Tourism Suitability Index; Diving; Nusa lembongan.

\section{PENDAHULUAN}

Pulau-pulau kecil memiliki potensi keanekaragaman hayati sumberdaya pesisir dan laut yang mampu menyajikan keindahan alam. Salah satu potensi keanekaragaman hayati pesisir dan laut yaitu ekosistem terumbu karang. Ekosistem terumbu karang memiliki nilai ekologi dan estetika yang tinggi serta kaya akan keanekaragaman biota (Nontji, 2002; Nybakken, 1992). Keindahan dan keanekaragaman biota pada ekosistem terumbu karang ini berpotensi untuk pengembangan ekowisata bahari. Kegiatan ekowisata bahari memiliki nilai keuntungan ekonomi yang tinggi jika pemanfaatannya dilakukan secara lestari (Cesar dkk., 2003). Pulau Nusa Lembongan memiliki potensi utama wisata bahari yang memanfaatkan keindahan ekosistem terumbu karang yaitu pada aktivitas wisata snorkeling dan selam.

Nilai ekonomis yang tinggi dan pemanfaatan terhadap ekosistem terumbu karang dikhawatirkan akan menyebabkan 
penurunan kualitas lingkungan dan kerusakan ekologis pada ekosistem ini. Hampir $71 \%$ terumbu karang di indonesia mengalami kerusakan yang cukup berat, yang relatif baik $22,5 \%$, sedangkan kondisi baik hanya sekitar 6,5\% (Suprihayono, 2000). Dalam pengembangan dan pengelolaan kawasan perairan Nusa Lembongan sebagai daerah tujuan utama wisata bahari khususnya wisata selam yang memanfaatkan keindahan terumbu karang oleh pemerintah Kabupaten Klungkung tentu diperlukan suatu data dan informasi dalam strategi pengembangan wisata selam berkelanjutan. Hal tersebut perlu didukung oleh data mengenai penilaian kesesuaian dan daya dukung ekosistem terumbu karang untuk dikembangkan sebagai wisata selam. Penilaian kesesuaian ini dapat memberikan gambaran seberapa sesuai suatu daerah ekosistem terumbu karang untuk dapat dijadikan sebagai daerah wisata selam.

\section{METODOLOGI}

\subsection{Waktu dan Lokasi Penelitian}

Pengamatan terhadap ekosistem terumbu karang dilaksanakan pada perairan Nusa Lembongan, Bali dari bulan Juli hingga September 2018. Perairan Pulau Nusa Lembongan termasuk kedalam kawasan konservasi perairan nusa penida. Terdapat 3 titik pengamatan (Jack Mangrove, Crystal Bay, dan Manta Bay) dengan 2 stasiun pengamatan pada masing-masing titik (Gambar 1) yang merupakan dive site wisata selam.

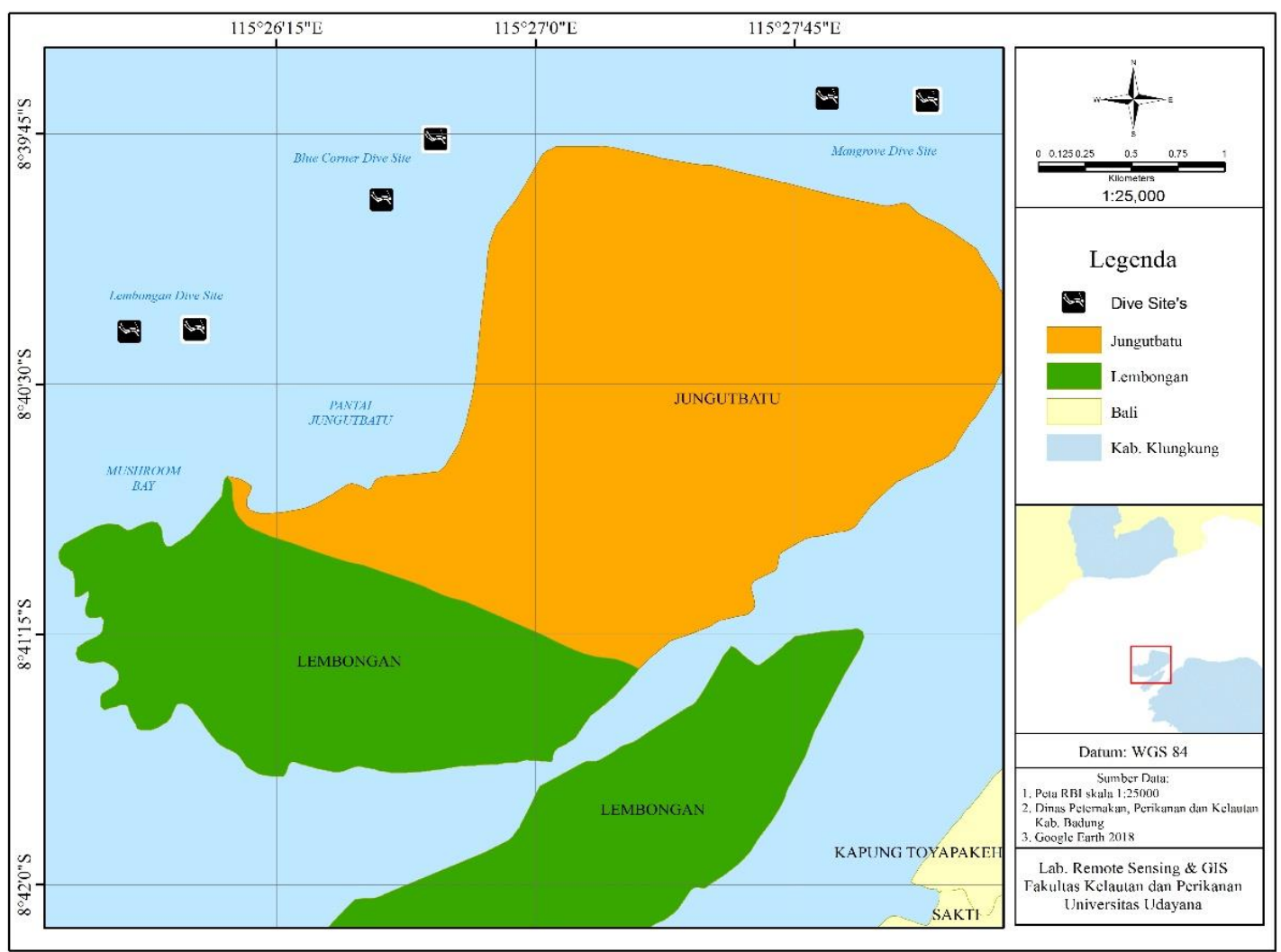

Gambar 1.

Peta Lokasi Penelitian di Pulau Nusa Lembongan 


\subsection{Teknik Pengumpulan Data Terumbu Karang}

Pengamatan terumbu karang dilakukan terhadap parameter bentuk pertumbuhan terumbu karang dan tutupan komunitas karang. Pengamatan dilakukan dengan menggunakan metode LIT (Line Intercept Transect) (English et al. 1997). Transek garis pada pengamatan terumbu karang menggunakan roll meter yang dibentangkan sepanjang 50 meter sejajar dengan garis pantai. Identifikasi lifeform terumbu karang menurut versi AIMS (Australian Institute of Marine Science).

\section{A. Ikan Karang}

Pengamatan kondisi ikan terumbu dilakukan terhadap parameter jenis dan jumlah ikan terumbu. Pengamatan dilakukan dengan metode visual sensus yaitu mencatat jenis dan jumlah per jenis ikan yang ditemukan sepanjang transek 50 meter (Hill dan Wilkinson, 2004). Jarak pandang yang digunakan dalam pengamatan yaitu 5 meter $(2.5 \mathrm{~m} \mathrm{ke}$ kanan dan $2.5 \mathrm{~m}$ ke kiri) dari transek, kemudian ke arah depan sepanjang transek garis yaitu 50 meter. Identifikasi spesies ikan terumbu pada transek menggunakan Buku dan Marine Fishes (Allen, 1997) dan Indonesian Reef Fishes (Kuiter dan Takamasa 2001).

\section{B. Kualitas Perairan}

Pengamatan kualitas perairan dilakukan terhadap parameter kecerahan perairan, kedalaman terumbu karang dan kecepatan arus. Kecerahan perairan diamati dengan menggunakan secchi disk. Kedalaman pada setiap stasiun saat melakukan penyelaman merupakan kedalaman yang digunakan pada parameter. Current meter digunakan dalam pengamatan terhadap parameter kecepatan arus.

\subsection{Analisis Data}

Indeks kesesuaian wisata (IKW) merupakan indeks untuk menilai kelayakan kawasan sebagai kawasan ekowisata. Kajian mengenai kesesuaian ekowisata bahari selam dihitung berdasarkan kondisi biofisik di lokasi pengamatan. Nilai pengamatan dari masing-masing parameter kesesuaian ekowisata selam diberi skor berdasarkan matrik kesesuaian wisata selam (Tabel 1), kemudian dianalisis dengan menggunakan rumus Indeks Kesesuaian Wisata (Yulianda, 2007):

$\mathrm{IKW}=\left[\sum \mathrm{Ni} / \mathrm{Nmaks}\right] \times 100 \%$

Keterangan :

IKW : Indeks Kesesuaian Wisata (\%)

Ni: Nilai parameter ke-I (Bobot x skor)

Nmaks: Nilai maksimum $($ selam $=54)$

Indeks kesesuaian wisata (IKW) selam dikategorikan menjadi sangat sesuai, sesuai dan tidak sesuai. Kategori sangat sesuai didapatkan apabila nilai IKW sebesar 75\%-100\%, sesuai untuk nilai IKW sebesar $50 \%-75 \%$ dan tidak sesuai untuk nilai IKW $<50 \%$. Jika suatu kawasan termasuk dalam kategori sesuai atau sangat sesuai maka dibutuhkan analisis daya dukung kawasan untuk dapat membatasi tekanan ekosistem terumbu karang dari kegiatan wisata selam. 
Tabel 1. Matrik Kesesuaian wisata selam (Yulianda, 2007)

\begin{tabular}{|c|c|c|c|c|c|c|c|c|c|c|}
\hline No & Parameter & Bobot & $\begin{array}{l}\text { Kategori } \\
\text { S1 }\end{array}$ & Skor & $\begin{array}{l}\text { Kategori } \\
\text { S2 }\end{array}$ & Skor & $\begin{array}{c}\text { Kategori } \\
\quad \text { S3 }\end{array}$ & Skor & $\begin{array}{l}\text { Kategori } \\
\text { TS }\end{array}$ & Skor \\
\hline 1. & $\begin{array}{l}\text { Kecerahan } \\
\text { perairan }(\%)\end{array}$ & 5 & $>80$ & 3 & $50-80$ & 2 & $20-<50 \%$ & 1 & $<20$ & 0 \\
\hline 2. & $\begin{array}{l}\text { Tutupan } \\
\text { komunitas } \\
\text { karang (\%) }\end{array}$ & 5 & $>75$ & 3 & $>50-75$ & 2 & $25-50$ & 1 & $<25$ & 0 \\
\hline 3. & Jenis life form & 3 & $>12$ & 3 & $<7-12$ & 2 & $4-7$ & 1 & $<4$ & 0 \\
\hline 4. & Jenis ikan karang & 3 & $>100$ & 3 & $50-100$ & 2 & $20-<50$ & 1 & $<20$ & 0 \\
\hline 5. & $\begin{array}{l}\text { Kecepatan arus } \\
(\mathrm{cm} / \mathrm{dt})\end{array}$ & 1 & $0-15$ & 3 & $>15-30$ & 2 & $>30-50$ & 1 & $>50$ & 0 \\
\hline 6. & $\begin{array}{l}\text { Kedalaman } \\
\text { terumbu karang } \\
\text { (m) }\end{array}$ & 1 & $6-15$ & 3 & $\begin{array}{c}>15-20 \\
3-<6\end{array}$ & 2 & $>20-30$ & 1 & $\begin{array}{l}>30 \\
<3\end{array}$ & 0 \\
\hline
\end{tabular}

Indeks kesesuaian wisata (IKW) selam dikategorikan menjadi sangat sesuai, sesuai dan tidak sesuai. Kategori sangat sesuai didapatkan apabila nilai IKW sebesar $75 \%-100 \%$, sesuai untuk nilai IKW sebesar $50 \%-75 \%$ dan tidak sesuai untuk nilai IKW $<50 \%$. Jika suatu kawasan termasuk dalam kategori sesuai atau sangat sesuai maka dibutuhkan analisis daya dukung kawasan untuk dapat membatasi tekanan ekosistem terumbu karang dari kegiatan wisata selam.

\section{HASIL DAN PEMBAHASAN}

\subsection{Kualitas Perairan}

Hasil pengukuran arus pada setiap stasiun rata-rata $0,2 \mathrm{~m} / \mathrm{s}$. Namun pada stasiun 2 arus lebih rendah dari pada stasiun 1 dan stasiun 3 (Tabel 2). Hasil pengukuran derajat keasaman $(\mathrm{pH})$ pada setiap stasiun memiliki nilai yang sama yakni 7,02. Nilai tersebut masih dalam kategori baku mutu optimal untuk biota laut. Hasil pengukuran salinitas pada setiap stasiun berkisar antara 33,3-39 ppt. Pergub Bali (2016), bahwa baku mutu dalam kehidupan biota laut memiliki salinitas kisaran untuk hidup antara 33-34 ppt. Pada pengukuran ini, titik dengan salinitas optimal terdapat pada stasiun 2 sedangkan titik 1 dan 3 memiliki nilai salinitas tinggi. Hasil pengukuran kecerahan pada setiap stasiun berkisar antara 11-15 m. Titik dengan kecerahan paling tinggi yakni pada stasiun 1 bernilai $15 \mathrm{~m}$. Titik dengan kecerahan paling rendah yakni pada stasiun 2 bernilai $11 \mathrm{~m}$. Stasiun 3 memiliki nilai kecerahan $14 \mathrm{~m}$. Hal ini termasuk kategori optimal yakni diatas 5 meter sesuai dengan baku mutu (Pergub Bali, 2016). Hasil pengukuran suhu pada setiap stasiun berkisar antara 21-29 ${ }^{\circ}$ C. Suhu optimal sesuai dengan baku mutu adalah kisaran $28-30^{\circ} \mathrm{C}$. Nilai suhu pada stasiun 1 dan 2 tergolong kurang optimal karena tidak sesuai dengan baku mutu (Pergub Bali, 2016). Namun nilai suhu pada stasiun 3 tergolong optimal yakni $29^{\circ} \mathrm{C}$. 
Tabel 2. Hasil Pengamatan Kondisi Kualitas Perairan di Nusa Lembongan

\begin{tabular}{|c|c|c|c|c|c|c|c|}
\hline \multirow{2}{*}{$\begin{array}{c}\text { Kualitas } \\
\text { Air }\end{array}$} & \multicolumn{2}{|c|}{ Jack Mangrove } & \multicolumn{2}{|c|}{ Crystal Bay } & \multicolumn{2}{|c|}{ Manta Bay } & \multirow{2}{*}{$\begin{array}{c}\text { Baku } \\
\text { Mutu** }\end{array}$} \\
\hline & Stasiun 1 & Stasiun 2 & Stasiun 1 & Stasiun 2 & Stasiun 1 & Stasiun 2 & \\
\hline Arus & $0,2 \mathrm{~m} / \mathrm{s}$ & $0,2 \mathrm{~m} / \mathrm{s}$ & $0,1 \mathrm{~m} / \mathrm{s}$ & $0,1 \mathrm{~m} / \mathrm{s}$ & $0,2 \mathrm{~m} / \mathrm{s}$ & $0.1 \mathrm{~m} / \mathrm{s}$ & \\
\hline $\mathrm{pH}$ & 7,02 & 7,2 & 7,02 & 7302 & 7,02 & 7,02 & $7-8,5$ \\
\hline Salinitas & $39 \mathrm{ppt}$ & $39 \mathrm{ppt}$ & $33,3 \mathrm{ppt}$ & $33,3 \mathrm{ppt}$ & $35,7 \mathrm{ppt}$ & $35.6 \mathrm{ppt}$ & $33-34 \mathrm{ppt}$ \\
\hline Kecer & & & & & 15 & & \\
\hline Suhu & $29^{\circ} \mathrm{C}$ & $29^{\circ} \mathrm{C}$ & $25^{\circ} \mathrm{C}$ & $25^{\circ} \mathrm{C}$ & $21^{\circ} \mathrm{C}$ & $21{ }^{\circ} \mathrm{C}$ & $28-30^{\circ} \mathrm{C}$ \\
\hline
\end{tabular}

*Sumber: Pergub Bali (2016)

\subsection{Tutupan Komunitas Karang}

Hasil pengamatan terhadap tutupan komunitas karang didapatkan bahwa komponen biotik dan abiotik memiliki kategori beragam. Ekosistem terumbu karang dapat dikatakan dalam kondisi baik apabila persentase penutupan karang hidup lebih besar daripada persentase tutupan abiotiknya. Persentase komponen biotik tertinggi pada Perairan Jack Mangrove relatif tinggi dengan nilai persentase karang hidup sebesar $82.20 \%$ di stasiun 1 dan nilai persentase pada stasiun 2 adalah $92.06 \%$. Selain karang hidup, terdapat komponen lain seperti Anemon dengan nilai $0.3-0.74 \%$, Acidiams 1.22\%, Turf Alga 1.8-11.40\% dan Sponge sebesar $1.10 \%$. Persentase komponen abiotik pada perairan Jack Mangrove retif kecil dengan nilai tutupan pasir sebesar 1.92-2.62\% dan batu dengan nilai 2-2.64\% (Tabel 3).

Persentase komponen biotik pada Perairan Manta Bay relatif sedang dengan nilai persentase karang hidup sebesar $21.80 \%$ di staisun 1 dan $65.66 \%$ di stasiun 2. selain karang hidup, terdapat komponen lain seperti Alga dengan nilai $1.54 \%$, dan turf alga sebesar $33.02 \%$. Nilai persentase komponen abiotik seperti pasir pada perairan Crystal Bay sebesar $45.18 \%$, batu $14.56 \%$, dan patahan karang sebesar $0.22 \%$. Persentase komponen biotik tertinggi pada Perairan Manta Bay relatif sedang dengan nilai persentase karang hidup sebesar $43.86 \%$ di staisun 1 dan $63.22 \%$ di stasiun 2. selain karang hidup, terdapat komponen lain seperti
Alga dengan nilai 4.84-11.22\%, karang mati beralga sebesar $0.84 \%$. Nilai persentase komponen abiotik seperti pasir pada perairan Jack Mangrove sebesar $11.92 \%$, batu $11.12 \%$, Slop $2.66 \%$, patahan karang sebesar 25.66\% (Tabel 3). Berdasarkan urairan diatas dapat disimpulkan bahwa persentase tutupan karang berkisar antara 21.8\% - 92.06\%. Jika semakin tinggi persentase tutupan karang yang didapatkan maka dapat dikatakan bahwa semakin baik kondisi ekosistem terumbu karang tersebut. Semakin tinggi persentase tutupan terumbu karang keras maka kondisi ekosistem terumbu karang semakin baik (Muqsit, 2016). Rendahnya nilai tutupan karang pada titik pengamatan Crystal Bay dapat disebabkan oleh kerusakan lingkungan akibat aktivitas manusia. Kerusakan terumbu karang yang diakibatkan oleh manusia yaitu berupa penambangan karang dengan atau tanpa menggunakan bahan peledak, pengurukan disekitar terumbu karang, parawisata dan lainnya (Dahuri et al., 2008). Tuhumena et al. (2014) juga menyatakan bahwa nilai persentase tutupan terumbu karang di Desa Mokupa memiliki kisaran antara 0,4-67,4\% yang diduga disebabkan oleh aktifitas manusia dan salinitas. Penurunan daya dukung lingkungan khususnya pada ekosistem terumbu karang dapat disebebakan oleh tingginya aktivitas dan interaksi manusia dengan lingkungannya (Prasetia dan Wisnawa, 2015). 
Tabel 3. Persentase Tutupan Komponen Biotik dan Abiotik di Nusa Lembongan

\begin{tabular}{|c|c|c|c|c|c|c|c|}
\hline \multirow{2}{*}{\multicolumn{2}{|c|}{ Komponen }} & \multicolumn{2}{|c|}{ Jack Mangrove } & \multicolumn{2}{|c|}{ Crystal Bay } & \multicolumn{2}{|c|}{ Manta Bay } \\
\hline & & Stasiun 1 & Stasiun 2 & Stasiun 1 & Stasiun 2 & Stasiun 1 & Stasiun 2 \\
\hline \multicolumn{8}{|l|}{ Biotik } \\
\hline & Karang & 82.2 & 92.06 & 21.8 & 65.66 & 43.86 & 63.22 \\
\hline & Anemon & 0.74 & 0.3 & - & - & - & - \\
\hline & Acidiams & - & 1.22 & - & - & - & - \\
\hline & Alga & - & - & - & 1.54 & 11.22 & 4.84 \\
\hline & Turf Alga & 11.4 & 1.8 & 33.02 & - & - & - \\
\hline & $\begin{array}{l}\text { Karang Mati } \\
\text { Beralga }\end{array}$ & - & - & - & - & - & 0.84 \\
\hline & Sponge & 1.1 & - & - & - & - & - \\
\hline \multicolumn{8}{|l|}{ Abiotik } \\
\hline & Pasir & 1.92 & 2.62 & 45.18 & 18.02 & - & 11.92 \\
\hline & Karang Mati & - & - & - & - & - & - \\
\hline & Batu & 2.64 & 2 & - & 14.56 & 19.26 & 11.12 \\
\hline & Slop & - & - & - & - & - & 2.66 \\
\hline & Patahan Karang & - & - & - & 0.22 & 25.66 & 5.4 \\
\hline
\end{tabular}

\subsection{Jenis Life Form}

Terdapat 12 jenis life form yang ditemukan di perairan Nusa Lembongan (Tabel 4). Pada masing-masing titik pengamatan memiliki jumlah jenis life form yang beragam dengan jumlah jenis tertinggi didapatkan pada titik pengamatan jack mangrove sebanyak 7 jenis, dan terendah didapatkan pada titik pengamatan Manta Bay sebanyak 3 jenis. Persentase jenis life form tertinggi yaitu pada jenis Coral Mushroom sebesar $47.55 \%$ dan terendah pada jenis Coral Foliose sebesar $0.8 \%$.

Tabel 4. Persentase Jenis life form di Nusa Lembongan

\begin{tabular}{lcccccc}
\hline \multirow{2}{*}{ Jenis Life Form } & \multicolumn{2}{c}{ Jack Mangrove (\%) } & \multicolumn{2}{c}{ Crystal Bay (\%) } & \multicolumn{2}{c}{ Manta Bay (\%) } \\
\cline { 2 - 7 } & Stasiun 1 & Stasiun 2 & Stasiun 1 & Stasiun 2 & Stasiun 1 & Stasiun 2 \\
\hline Acropora Digitate & 28.42 & 2.45 & 10.37 & - & - & 9.36 \\
Acropora Tabulate & 8.59 & 23.51 & 43.12 & 5 & - & - \\
Acropora Branching & 35.04 & 25.94 & - & 8.83 & - & - \\
Acropora Submasive & 9.81 & - & - & - & - & - \\
Acropora Mushroom & - & - & - & - & 54.95 & - \\
Coral Mushroom & 7.62 & - & 7.34 & 22.75 & - & 47.55 \\
Coral Helipora & 9.73 & - & - & - & - & - \\
Coral Foliose & 0.8 & 12.86 & - & - & - & 3.2 \\
Coral Massive & - & 6.54 & 10.09 & 38.87 & 40.63 & 36.22 \\
Coral Encrusting & - & 3.43 & - & 13.52 & - & 3.67 \\
Coral Branching & - & 25.27 & 29.08 & 11.03 & - & - \\
Coral Submassive & - & - & - & - & 4.42 & - \\
\hline
\end{tabular}

\subsection{Jenis dan Kelimpahan Ikan Karang}

Pada Titik pengamatan Jack Mangrove terdapat 331 jumlah ikan karang dengan 14 spesies. Pada staisun 1 terdapat 140 ekor dengan 11 spesies yang berbeda (Tabel 5). Pada stasiun ini persentase ikan karang di dominasi oleh 
spesies Pomacentrus moluccensis yakni sebesar 32.14\%. Pada Stasiun 2 terdapat 191 ekor dengan 13 spesies yang berbeda. Pada stasiun ini persentase ikan karang di dominasi oleh spesies Chromis scotochiloptera yakni sebesar $44.50 \%$. Spesies Pomacentrus moluccensis yang mendominasi pada stasiun 1 merupakan jenis ikan mayor yang merupakan ikan yang ditemukan dalam jumlah banyak pada ekosistem terumbu karang. Pada suatu eksosietem terumbu karang, adanya dominasi dari spesies mayor mengindikasikan bahwa pemanfaatan ikan target sebagai ikan konsumsi lebih banyak dari pada pemanfaatan kelompok mayor sebagai ikan hias (Rondonuwu, 2014).

Tabel 5. Jenis Ikan Karang

\begin{tabular}{|c|c|c|c|c|c|c|}
\hline \multirow{2}{*}{ Jenis Ikan Karang } & \multicolumn{2}{|c|}{ Jack Mangrove } & \multicolumn{2}{|c|}{ Crystal Bay } & \multicolumn{2}{|c|}{ Manta Bay } \\
\hline & Stasiun 1 & Stasiun 2 & Stasiun 1 & Stasiun 2 & Stasiun 1 & Stasiun 2 \\
\hline Acanthurus nigricans & - & - & - & & 9.09 & 4 \\
\hline Chaetodon klenii & 8.57 & 5.24 & 7.22 & 5.49 & 27.27 & 28 \\
\hline Chromis margaritifera & - & - & - & & 13.64 & 20 \\
\hline $\begin{array}{l}\text { Hemiglyphidodon } \\
\text { plagiometopon }\end{array}$ & - & - & - & & 4,55 & 12 \\
\hline Melichthys vidua & - & - & - & & 27.27 & - \\
\hline Scarus quoyi & - & - & - & & 4.55 & 4 \\
\hline Pomacentrus auriventris & - & - & 18.56 & 13.19 & 4.55 & 20 \\
\hline Thalassoma hardwick & - & - & - & & 4.55 & 4 \\
\hline Zanclus cornutus & 7.14 & 4.71 & 5.15 & 9.89 & 4.55 & 8 \\
\hline Epibulus cornutus & - & - & 4.12 & 3.3 & - & - \\
\hline Parupeneus cyclustumus & - & - & 3.09 & 7.69 & - & - \\
\hline Pomacentrus trimaculatus & - & - & 4.12 & 2.2 & - & - \\
\hline Pomacentrus moluccensis & 32.14 & 19.37 & 2.06 & & - & - \\
\hline Acanthurus pyroferus & - & - & 11.34 & 17.58 & - & - \\
\hline Chaetodon melannotus & - & - & 2.06 & 4.4 & - & - \\
\hline Chaetodon auriga & - & - & 2.06 & & - & - \\
\hline Hemitaurichthys polylepis & - & - & 1.03 & 3.3 & - & - \\
\hline Ostracion meleagris & - & - & 1.03 & 1.1 & - & - \\
\hline Siganus punctatissimus & - & - & 3.09 & 8.79 & - & - \\
\hline Epinephelus merra & - & - & 1.03 & 5.49 & - & - \\
\hline Chromis scotochiloptera & 14.29 & 44.5 & 34.02 & 17.58 & - & - \\
\hline Platax pinnatus & 21.43 & 20.42 & - & - & - & - \\
\hline Melichthys niger & 4.29 & 0.52 & - & - & - & - \\
\hline Pseudanthias huchtii & 1.43 & 1.05 & - & - & - & - \\
\hline Scolopsis xenochroa & 1.43 & 0.52 & - & - & - & - \\
\hline Acanthurus auranticavus & 1.43 & 1.05 & - & - & - & - \\
\hline Amphiprion clarkii & 4.29 & 0.52 & - & - & - & - \\
\hline Chaetodon triangulum & 3.57 & 1.05 & - & - & - & - \\
\hline Plectrochinchus lineatus & - & 0.52 & - & - & - & - \\
\hline Balistoides conspicillum & - & 0.52 & - & - & - & - \\
\hline
\end{tabular}

Pada titik pengamatan Crystal Bay terdapat 188 jumlah ikan karang dengan 15 spesies. Pada Stasiun 1 terdapat 97 ekor dengan 15 spesies yang berbeda yang dominasi oleh Chromis scotochiloptera yakni sebesar $34.02 \%$. Pada stasiun 2 terdapat jumlah 91 ekor dengan 13 spesies yang berbeda yang didominasi oleh spesies Chromis scotochiloptera dan spesies Achanturus pyroferus yakni sebesar $17,58 \%$. Pada stasiun 1 dan 2 memiliki spesies ikan karang yang cenderung sama namun tidak ditemukan spesies Pomacentrus moluccensis dan Chaetodon auriga pada stasiun 2.

Titik pengamatan Manta Bay terdapat 47 ikan karang dengan 9 spesies. 
Stasiun 1 berjumlah 22 ekor dan Stasiun 2 berjumlah 25 ekor. Stasisun ini di dominasi oleh spesies Chaetodon kleinii dan Pomacentris auriventris yakni sebesar $27.27 \%$. Pada stasiun 2 ini persentase ikan karang di dominasi oleh spesies Chaetodon kleinii yakni sebesar $28.0 \%$. Perbedaan yang ditemukan yaitu pada stasiun 1 terdapat spesies Melichthys vidua sedangkan pada stasiun 2 tidak ditemukan, namun selebihnya sama.

Kelimpahan tertinggi terdapat pada titik pengamatan Jack Mangrove stasiun 2 yaitu sebesar 7640 ind/ha. Sedangkan kelimpahan terendah terdapat pada titik pengamatan Manta Bay Stasiun 1 yaitu sebesar 880 ind/ha (Gambar 2).

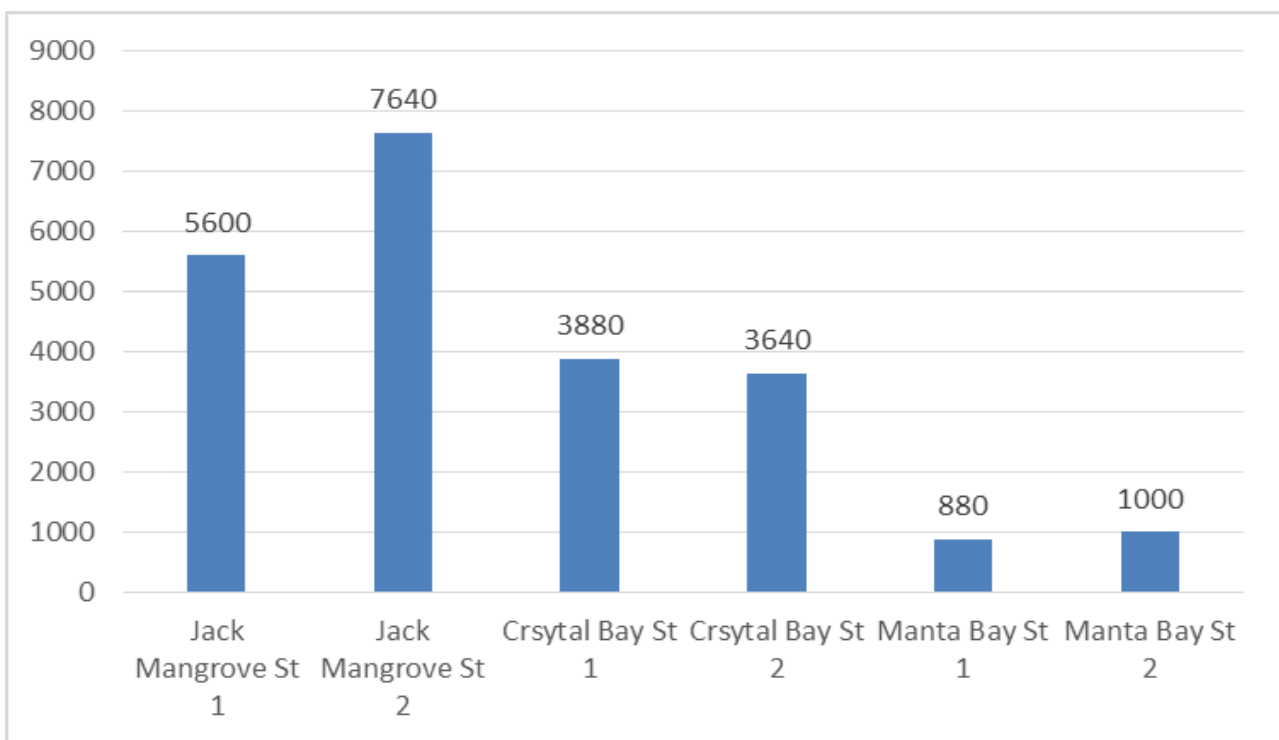

Gambar 2.

Kelimpahan Ikan Karang di Nusa Lembongan

\subsection{Indeks Kesesuaian Wisata}

Penilaian kesesuaian wisata pada wisata selam dilakukan terhadap 6 parameter di perairan Nusa Lembongan. Pada Tabel 6 dapat dilihat bahwa indeks kesesuaian wisata selam yaitu sebesar $74.07 \%$ pada titik pengamatan Jack Mangrove, sebesar $57.41 \%$ pada titik pengamatan Crystal Bay dan 61.11\%. Skor tertinggi terdapat pada parameter kecerahan perairan dan tutupan komunitas karang (Jack Mangrove); parameter kecerahan perairan dan kecepatan arus (Crsytal Bay); serta parameter kecerahan perairan dan kecepatan arus (Manta Bay). Sedangkan skor terendah pada setiap titik pengamatan terdapat pada parameter jenis ikan karang. Hal ini disebebkan oleh jenis ikan karang yang ditemukan pada setiap titik pengamatan tidak lebih dari 20 jenis.

Berdasarkan Yulianda (2007) nilai IKW yang didapatkan pada setiap titik pengamatan memiliki kisaran 50-75\%. Hal ini dapat diartikan bahwa pada setiap titik pengamatan termasuk dalam kategori sesuai untuk wisata selam. Penelitian pada perairan lainnya juga dilakukan terhadap kesesuaian wisata selam yaitu Koriyandi et al. (2016) di Pulau Kunyit yang termasuk kategori sangat sesuai; Leonard et al. (2014) di Pulau Biawak yang termasuk kategori sesuai dan sangat sesuai; Natha et al. (2014) di Pulau Nusa $\mathrm{Ra}$ dan Pulau Deket yang termasuk kategori sesuai, sangat sesuai dan sesuia bersyarat; Koroy et al. (2018) di Pulau Dodola yang termasuk kategori sesuai dan sangat sesuai. 
Tabel 6. Nilai Indeks Kesesuaian Wisata di Nusa Lembongan

\begin{tabular}{|c|c|c|c|c|c|c|c|c|c|c|}
\hline \multirow{2}{*}{ Parameter } & \multirow{2}{*}{ Bobot } & \multicolumn{3}{|c|}{ JACK MANGROVE } & \multicolumn{3}{|c|}{ CRSYTAL BAY } & \multicolumn{3}{|c|}{ MANTA BAY } \\
\hline & & Hasil & Skor & Nilai & Hasil & Skor & Nilai & Hasil & Skor & Nilai \\
\hline $\begin{array}{l}\text { Kecerahan perairan } \\
(\%)\end{array}$ & 5 & $8-15$ & 3 & 15 & $8-15$ & 3 & 15 & $14-15$ & 3 & 15 \\
\hline $\begin{array}{l}\text { Tutupan komunitas } \\
\text { karang }(\%)\end{array}$ & 5 & 87.13 & 3 & 15 & 45.24 & 1 & 5 & 53.54 & 2 & 10 \\
\hline Jenis life form & 3 & 12 & 2 & 6 & 8 & 2 & 6 & 6 & 1 & 3 \\
\hline Jenis ikan karang & 3 & 13 & 0 & 0 & 15 & 0 & 0 & 9 & 0 & 0 \\
\hline $\begin{array}{l}\text { Kecepatan arus } \\
(\mathrm{m} / \mathrm{s})\end{array}$ & 1 & 0.2 & 2 & 2 & 0.1 & 3 & 3 & 0.1 & 3 & 3 \\
\hline $\begin{array}{l}\text { Kedalaman } \\
\text { terumbu karang (m) }\end{array}$ & 1 & $15-17$ & 2 & 2 & $15-17$ & 2 & 2 & $14-15$ & 2 & 2 \\
\hline & & & Total & 40 & & Total & 31 & & Total & 33 \\
\hline & & & IKW & 74.07 & & IKW & 57.41 & & IKW & 61.11 \\
\hline
\end{tabular}

\section{SIMPULAN}

Nilai indeks kesesuaian wisata untuk kategori wisata selam yang didapatkan yaitu sebesar $74.07 \%$ (Jack Mangrove); $57.41 \%$ (Crystal Bay); dan $61.11 \%$ (Manta Bay). Nilai IKW setiap titik pengamatan termasuk pada kategori sesuai untuk nilai IKW sebesar 50\%-75\%. Hal ini dapat diartikan bahwa semua titik pengamatan yang merupakan lokasi penyelaman di Nusa Lembongan telah mendukung untuk dilakukan kegiatan wisata selam.

\section{UCAPAN TERIMAKASIH}

Kepada Lembaga Penelitian dan Pengabdian Kepada Masyarakat (LPPM) Universitas Udayana, Dekan Fakultas Kelautan dan Perikanan, Fakultas Kelautan dan Perikanan Universitas Udayana, Masyarakat Desa Jungut Batu Nusa Lembongan, dan Tim peneliti.

\section{DAFTAR PUSTAKA}

Allen, G., Swainston, R., Ruse, J. 1997. Marine Fishes of Tropical Australia and South-East Asia: A Field Guide for Anglers and Divers. Singapore (SG): Periplus Editions (HK) Ltd. Bengen, D.G. 2002. Sinopsis Ekosistem Sumberdaya Alam Pesisir dan Laut serta Prinsip Pengelolaannya. Pusat Kajian Sumberdaya Pesisir dan Lautan, Institut Pertanian Bogor. Bogor

Badan Pusat Statistik Kabupaten Klungkung. 2012. Kabupaten Klungkung dalam Angka. Kabupaten Klungkung, Bali.

Bruce, D., Hoctor, Z., Garrod, B., Wilson, J. 2002. Planning for Marine Ecotourism in the UE Atlantic Area. META-Project. Bristol: University of the Weat England.

Burke, L., Selig, E., Spalding, M. 2002. Reefs at Risk in Southeast Asia. World Resource Institute. Washington DC. USA.72p

Casagrandi, R., Rinaldi, S. 2002. A Theoretical Approach to Tourism Sustainability. International Institute for Applied Systems Analysis Schlossplatz 1 A-2361 Laxenburg, Austria.

Cesar, H.L., Burke, Pet-Soede. 2003. The Economic of World Wide Coral Reef Degradation. Cesar Environmental Economic. Consulting: Arnhen (Netherlands). 
Dahuri, H.R., Rais, J., Ginting, S.P., Sitepu, M.J. 2008. Pengelolaan Sumber Daya Wilayah Pesisir dan Lautan Secara Terpadu. Penerbit PT. Pradnya Paramita, Jakarta. Ed. Rev.,cet. ke-4. Hal. $197-201$.

English, S., Wilkinson, C., Baker V. 1994. Survey Manual for Tropical Marine Resources. Australian Institut of Marine Science. Townville (AU). 34-80p.

English, S., Wilkinson C., Baker, V. 1997. Survey Manual for Tropical Marine Resources. Ed ke-2. Townsville: Australian Institute of Marine Science.

Kuiter J, Takamasa T. 2001. Indonesian Reef Fishes (Part 1). Australia (AU): Zoonetics

Kuiter J, Takamasa T. 2001. Indonesian Reef Fishes (Part 2). Australia (AU): Zoonetics

Kuiter J, Takamasa T. 2001. Indonesian Reef Fishes (Part 3). Australia (AU): Zoonetics

Koriyandi, A., Hamdani, Salim, D. 2016. Analisis Kesesuaian Wisata Diving di Kawasan Perairan Pulau Kunyit Sebelah Timur Kecamatan Pulau Laut Tanjung Selayar Kabupaten Kotabaru. EnviroScienteae, 12 (3): 181-193

Koroy, N.K., Mustafa, M. 2018. Analisis Kesesuaian Dan Daya Dukung Ekosistem Terumbu Karang Sebagai Ekowisata Bahari Di Pulau Dodola Kabupaten Pulau Morotai. Jurnal Enggano, 3(1): 52-64

Leonard, O.J., Pratikto, I., Munasik. 2014. Kesesuaian Perairan Untuk Wisata Selam Dan Snorkeling Di Pulau Biawak, Kabupaten Indramayu. Journal of Marine Research, 3(3): 216-225

Muqsit, A., Purnama, D., Ta'alidin, Z. 2016. Struktur Komunitas Terumbu Karang Di Pulau Dua Kecamatan
Enggano Kabupaten Bengkulu Utara. Jurnal Enggano, 1(1): 75-87

Natha, M.H., Tuwo, A., Samawi, F. 2014. Kesesuaian Ekowisata Selam Dan Snorkling Di Pulau Nusa Ra dan Nusa Deket Berdasarkan Potensi Biofisik Perairan. J. Sains \& Teknologi, 14(3): 259-268

Nybakken, J.W. 1998. Biologi Laut: Suatu Pendekatan Ekologis. Terj. Dari Marine Biology: An Ecology Approach, oleh Eidman M, Koesoebiono DG, Bengen, Hutomo M, Sukardjo S. 1992. Jakarta (ID): PT Gramedia Pustaka Utama.

Nontji, A. 1987. Laut Nusantara. Jakarta. Penerbit Jambatan

Orams, M. 1999. Marine Tourism : Development, Impact and Management. Rutledge. London.

Prasetia, I.N.D., Wisnawa, I.G.Y. 2015. Struktur Komunitas Terumbu Karang Di Pesisir Kecamatan Buleleng Singaraja. Jurnal Sains dan Teknologi, 4(2): 579-590

Romimohtarto, K. dan S. Juwana. 2001. Biologi Laut :Ilmu Pengetahuan Tentang Biologi Laut. Penerbit Djambatan. Jakarta.

Rondonuwu, A.B., Rembet, U.N., Moningkey, R.Dj., Tombokan, J.L., Kambey, A. D., Wantasen, A.S. 2013. Coral fishes the famili chaetodontidae in coral reef waters of Para Island Sub District atoareng, Sangihe Kepulauan Regency. Jurnal Ilmiah Platax, 1(4): 210-215.

Suharsono. 1998. Kesadaran Masyarakat tentang Terumbu Karang (Kerusakan di Indonesia). LIPI. Jakarta.

Suharti, R. 1999. Ekologi Ikan Karang. http:www.Coremap. Or id/Download/EkologilkanKarang. Pdf.08-07-2014.

Tuhumena, J.R., Kusen, J.D., Paruntu, C.P. 2013. Struktur Komunitas 
Karang Dan Biota Asosiasi Pada Kawasan Terumbu Karang di Perairan Desa Minanga Kecamatan Malalayang II dan Desa Mokupa Kecamatan Tombariri. Jurnal Pesisir dan Laut Tropis, 3 (1): 6-12 Yulianda, F. 2007. Ekowisata Bahari Sebagai Alternatif Pemanfaatan Sumber daya Pesisir Berbasis
Konservasi. Seminar Sain Departemen MSP, FPIK IPB. BogorAdrianto L, Matsuda Y, Sakuma Y. 2005. Assesing Sustainability of Fishery Systems in A Small Island Region: Flag Modeling Approach. Proceeding of IIFET. 2005 